\title{
PENDAMPINGAN KEGIATAN DIPPING PUTING PADA TERNAK KAMBING PERAH DI DESA TURGO, TURI, SLEMAN, YOGYAKARTA
}

\author{
Clara Ajeng Artdita ${ }^{1 *}$, Morsid Andityas ${ }^{1}$, Ronny Martien², Maria Advensia Eka \\ Setyaningrum ${ }^{1}$, Achmad Fauzi ${ }^{1}$ \\ ${ }^{1}$ Program Studi Kesehatan Hewan Sekolah Vokasi Universitas Gadjah Mada; \\ ${ }^{2}$ Fakultas Farmasi Universitas Gadjah Mada \\ *Email : clara.ajeng@ugm.ac.id
}

\begin{abstract}
Dipping is one of the main process for the stage of milking process and it serves to prevent the the bacteria infected the udder on post-milking process. Mastitis can occur because of this stage not being carried out. The program partner is in the Turgo village, Turi, Sleman, Yogyakarta. This partner has obstacles in the magement of Ettawa crossbreed (PE) goat productivity including milking goat Standard Operating Management (SOP). The purpose of $\mathrm{t}$ his community service is to make farmer feel easier to do the dipping method by using herbal-based products sprayer to be applied to PE goats after milking to prevent occurence of mastitis. The method of this program is introducing PE goat cultivation by applying the concept of good farming practices and the importance of preventing mastitis, utilizing home yard to plant Piper betle linn. As a basis for making teat dip sprayer, and improving the productivity of PDE goat as dairy goat with herbal teat dip sprayer using ionic gelation method. Teat dip sprayer technology on dairy goats is expected to increase the productivity of PE goat milk in this partner "Kelompok Ternak". The result is an increasing of farmer's understanding and the sustainability of milking SOP of dipping with herbal products which easy to apply (sprayer); So that the livestock health and productivity are increases, then it will impact in economic of this farmer community.
\end{abstract}

Keywords: dairy goat; mastitis; Piper betle linn.; teat dip sprayer

\begin{abstract}
Abstrak
Dipping merupakan proses pencelupan puting ambing ternak perah yang termasuk ke dalam tahapan proses pemerahan susu dan berfungsi untuk mencegah berkembangnya bakteri paska pemerahan. Kasus mastitis dapat terjadi akibat tahapan ini tidak dilakukan usai pemerahan. Mitra program ini adalah kelompok ternak di desa Turgo, Turi, Sleman, Yogyakarta. Mitra ini memiliki kendala dalam manajemen pengelolaan kambing PE produktif termasuk Standar Operasional Prosedur (SOP) dalam pemerahan susu kambing. Tujuan dari pengabdian ini adalah untuk memudahkan petani peternak dalam melakukan metode dipping dengan produk berbahan herbal untuk diaplikasikan pada ternak perahnya usai dilakukan pemerahan sebagai agen antibakterial untuk mencegah kejadian mastitis. Metode yang akan dilakukan melalui program ini yaitu memperkenalkan budidaya kambing PE dengan menerapkan konsep good farming practices dan pentingnya pencegahan mastitis, memanfaatkan pekarangan rumah untuk ditanami daun sirih hijau sebagai dasar pembuatan teat dip sprayer, dan memperbaiki produktivitas ternak perah dengan herbal teat dip sprayer menggunakan metode ionic gelation. Pemanfaatan teknologi teat dip sprayer pada kambing perah diharapkan dapat meningkatkan produktivitas susu kambing PE di Kelompok Ternak mitra ini. Hasil akhir berupa terbentuknya pemahaman peternak serta keberlanjutan SOP pemerahan berupa dipping dengan produk yang mudah pengaplikasiannya (sprayer) sehingga ternak sehat, produktivitas meningkat, dan ekonomi masyarakat pedesaan mampu terangkat.
\end{abstract}

Kata kunci: kambing perah; mastitis; daun sirih hijau; teat dip sprayer 


\section{PENDAHULUAN}

Susu kambing memiliki berbagai keuntungan bagi kesehatan manusia. Susu kambing banyak dikonsumsi karena sebagai alternatif bagi konsumen yang memiliki alergi terhadap susu sapi, selain itu kandungan nutrisi yang lebih baik dibandingkan dengan kandungan nutrisi pada susu sapi. Susu kambing juga mudah dicerna, hal ini disebabkan karena susu kambing memiliki ukuran butiran lemak yang lebih kecil dibandingkan susu sapi dan memiliki proporsi asam lemak rantai pendek dalam jumlah yang tinggi. Hal inilah yang menyebabkan pangsa pasar susu kambing semakin meningkat (Ceballos et al., 2009; Yangilar, 2013; Indrawati et al., 2015).

Perkembangan agribisnis ternak perah ini sebagai salah satu usaha tani berupa produksi susu berjalan cukup lamban. Hal ini disebabkan rendahnya keuntungan yang diperoleh para peternak. Susu kambing di Daerah Istimewa Yogyakarta (DIY)banyak diproduksi di daerah Kabupaten Sleman. Daerah tersebut merupakan kabupaten di propinsi DIY yang memiliki populasi kambing Peranakan Ettawah terbesar (Anonim, 2017) dan kebanyakan adalah berupa peternakan rakyat yang tergabung dalam kelompok ternak. Peningkatan perkembangan agribisnis ternak kambing perah, perlu dengan peningkatan keuntungan yang akan diterima oleh peternak. Oleh karena itu, peternak dituntut agar meningkatkan kesehatan ternaknya, mencegah dari penyakit terutama yang berimbas pada produksi susu namun tetap mengelola ternaknya secara efisien dan ekonomis sehingga dapat meningkatkan keuntungan. Penyakit yang sering terjadi pada ternak perah adalah mastitis (mastitis klinis dan subklinis). Mastitis subklinis menjadi perhatian khusus dikarenakan pada kasus ini, tidak muncul gejala klinis pada kambing perah namun produksi susu turun dan tentunya ini merugikan peternak (Koop et al., 2010; Marogna et al., 2012). Pencegahan dan pengendalian kejadian mastitis (radang ambing) dapat dilakukan dengan pemberian antibiotik, hanya saja ternak yang diberi perlakuan antibiotik biasanya ditolak pasar karena adanya residu antibiotik. Salah satu cara memperbaiki atau mengurangi kejadian mastitis adalah dengan melakukan perbaikan sistem manajemen pemeliharaan kesehatan. Salah satu manajemen pemeliharaan kambing PE adalah dipping dengan metode yang tepat sehingga akan diperoleh cara pengembangan sistem peternakan yang sesuai dengan Good Dairy Farming Practices (GDFP) pada peternakan rakyat (Koop et al., 2010; Indrawati et al., 2015).

Daun sirih hijau (Piper betle Linn.) memiliki aktivitas antibakteri yang tinggi. Bagian dari tanaman sirih yang dimanfaatkan sebagai obat adalah daunnya. Masyarakat awam menggunakan daun sirih untuk menyembuhkan luka kecil, perdarahan gusi dan obat kumur (Damayanti dan Mulyono, 2005). Hal ini dikarenakan daun sirih memiliki kandungan minyak atsiri sebanyak 4,2\% dan komponen utama dari minyak atsiri ini adalah bethel phenol dan turunannya yang bersifat antibakteri dan mampu mendenaturasi 
protein sel bakteri (Hasim, 2011). Hasil penelitian Artdita (2017) menyebutkan potensi yang dapat diaplikasikan dari herbal daun sirih dalam penggunaan sebagai pengobatan dan pencegahan mastitis.

\section{METODE PELAKSANAAN}

Metode yang digunakan dalam pemecahan permasalahan yaitu survei, penyuluhan, program pendampingan, pemantauan, dan evaluasi. Metode ini dikategorikan menjadi 3 tahapan, yaitu:

1. Pra kegiatan

Tahapan ini dilakukan dengan menggunakan metode berupa a). survei dan pengajuan perijinan lokasi pendampingan, $b$ ). penyuluhan tentang pentingnya kegiatan dipping puting dan diskusi dengan kelompok ternak terkait kondisi mastitis pada ternak kambing perah, sekaligus penyerahan bibit daun sirih hijau, c). cek status mastitis ternak kambing perah

2. Pelaksanaan kegiatan

Pelaksanaan kegiatan berupa a). program pendampingan pengaplikasian teat dip sprayer pada puting ternak perah selama 28 (dua puluh delapan) hari seusai pemerahan, b). pemantauan aplikasi dipping.

3. Evaluasi kegiatan

Kegiatan ini berupa evaluasi dan diskusi berdasarkan permasalahan yang muncul selama aplikasi dipping.

\section{HASIL DAN PEMBAHASAN}

Program kegiatan dipping puting kambing perah yang dilakukan di desa Turgo, Turi, Sleman, Yogyakarta ini bertujuan untuk mencegah pertumbuhan bakteri paska pemerahan. Mitra dalam kegiatan pendampingan ini adalah kelompok ternak di Desa Turgo, Turi, Sleman, Yogyakarta. Mitra tersebut memiliki kendala dalam manajemen pengolahan kambing PE produktif termasuk Standar Operasional Prosedur (SOP) dalam pemerahan susu. Adapun hasil yang diperoleh dari pelaksanaan program ini adalah sebagai berikut :

\subsection{Penyuluhan budidaya kambing PE dengan menerapkan konsep good dairy farming practice (GDFP)}

Peternak harus memiliki wawasan penerapan SOP pemerahan susu yang baik agar dapat mewujudkan konsep good dairy farming practice. Pengenalan konsep ini dilakukan melalui program sosialisasi interaktif menggunakan LCD proyektor dan presentasi power point sebagai media. Adapun kegiatan yang dilakukan yaitu memberikan edukasi tentang budidaya kambing PE, pencegahan mastitis, pemanfaatan lahan kosong untuk ditanami daun sirih sebagai bahan dasar pembuat teat dip sprayer dan memperbaiki produktivitas ternak perah dengan teknologi teat dip sprayer. Materi edukasi ini diberikan oleh drh. Ditya Bayu Pangesta. Antusiasme peternak terlihat saat proses diskusi dengan narasumber. Beberapa pertanyaan terkait manajemen GDFP yang baik, pencegahan mastitis dan penanganannya sempat dilontarkan.

Salah satu faktor penghambat yang menyebabkan rendahnya produktivitas kambing perah adalah minimnya pengetahuan peternak tentang aspek kesehatan hewan. Manajemen kesehatan 
yang buruk akan memicu timbulnya berbagai macam penyakit dan menimbulkan kerugian ekonomi, termasuk bakterial mastitis (Dash et al., 2016). Tim pengabdian melakukan survei menggunakan kuisioner untuk mengetahui tingkat pengetahuan peternak terhadap kesehatan dan penyakit pada kambing perah. Berdasarkan informasi yang diperoleh, sebagian besar peternak kambing perah di kelompok ternak Desa Turgo sudah mengetahui pentingnya manajemen kesehatan dan beberapa penyakit yang biasa menyerang kambing perah. Peternak umumnya mengetahui jenis-jenis penyakit hanya berdasarkan pengalaman pribadi dan akses untuk memperoleh informasi dari pihak medis veteriner masih sangat terbatas. Tindakan pencegahan yang dilakukan peternak yaitu mencelupkan (dipping) puting menggunakan alkohol $70 \%$, betadin ataupun chlorin (Leslie et al., 2006; Tomita et al., 2008).

Penggunaan antiseptik ini meninggalkan residu dan dapat menimbulkan iritasi (Flawchosky et al., 2014). Melihat kondisi demikian, tim pengabdian memberikan edukasi manajemen kesehatan ternak dan keterampilan pencegahan mastitis berupa pengolahan tanaman herbal daun Sirih sebagai bahan dipping pengganti antiseptik berbahan kimia tersebut. Daun sirih mengandung minyak atsiri yang mempunyai sifat antibakteri, sehingga diharapkan dapat menurunkan tingkat kejadian penyakit mastitis (Artdita, 2017). Pemberian dipping menggunakan daun sirih hijau ini dilakukan setelah pemerahan selesai dengan tujuan membersihkan saluran puting kambing dari kontaminasi bakteri. Hasilnya, pemberian dipping menggunakan daun Sirih mampu menurunkan kejadian mastitis di Kelompok Ternak Turgo.

\subsection{Penyuluhan \\ pemanfaatan pekarangan kandang untuk budidaya tanaman sirih hijau}

Permasalahan lain yang ditemui tim pengabdian masyarakat adalah keterbatasan bahan dasar pembuatan teat dip sprayer yaitu daun sirih. Di wilayah Turgo sangat jarang ditemukan tanaman sirih, padahal untuk membuat $20-30 \mathrm{ml}$ minyak atsiri membutuhkan kurang lebih $1-1,5 \mathrm{~kg}$ daun sirih segar.

Rumput liar dan semak banyak tumbuh di pekarangan sekitar kandang. Melihat kondisi ini, tim pengabdian berusaha untuk mengoptimalkan pekarangan kandang sebagai lahan budidaya daun sirih. Melalui kegiatan ini, tim pengabdian menyerahkan bibit daun sirih (Gambar 1) sekaligus melakukan praktik penanaman tanaman sirih disekitar kandang kelompok ternak Turgo bersama dengan para peternak.

\subsection{Peningkatan produktivitas ternak perah dengan pendampingan kegiatan teat dip sprayer}

Kejadian penyakit mastitis di Kelompok Ternak Turgo masih sangat tinggi. Hal ini menyebabkan penurunan perekonomian peternak berupa kematian ternak, penurunan produksi, dan meningkatkan biaya pengobatan. Oleh karena itui, tim pengabdian masyarakat berupaya untuk membuat metode dipping 
alternatif berbahan dasar daun sirih yang ditanam di sekitar kandang untuk dijadikan teat dip sprayer. Penggunaan teat dip sprayer diharapkan dapat membantu meningkatkan produktivitas ternak dari segi kesehatan terhadap penyakit mastitis. Aplikasi dipping tipe ini cukuplah mudah dan efisien, penggunaan teat dip sprayer berbahan dasar herbal ini teruji tidak mengganggu atau menurunkan kualitas hasil susu.

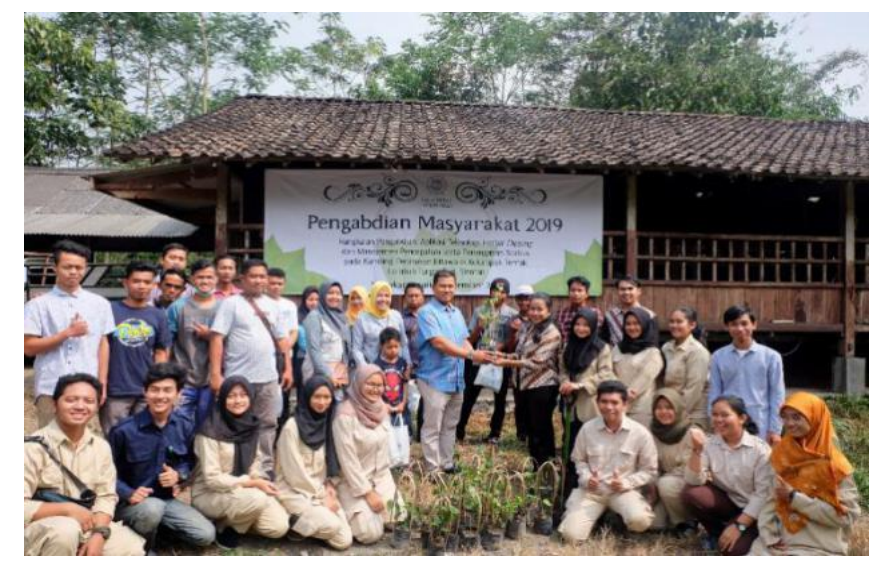

Gambar 1. Penyerahan bibit daun sirih hijau kepada kelompok ternak

Kemampuan daun sirih untuk setelah proses pemerahan (Gambar 2), hal membunuh bakteri penyebab mastitis ini dilakukan untuk mencegah bakteri telah teruji ampuh mencegah dan masuk melalui sphincter pada puting mengobati penyakit mastitis (Artdita, yang masih terbuka sesaat setelah 2017). Teat dip sprayer diberikan rutin pemerahan berakhir.

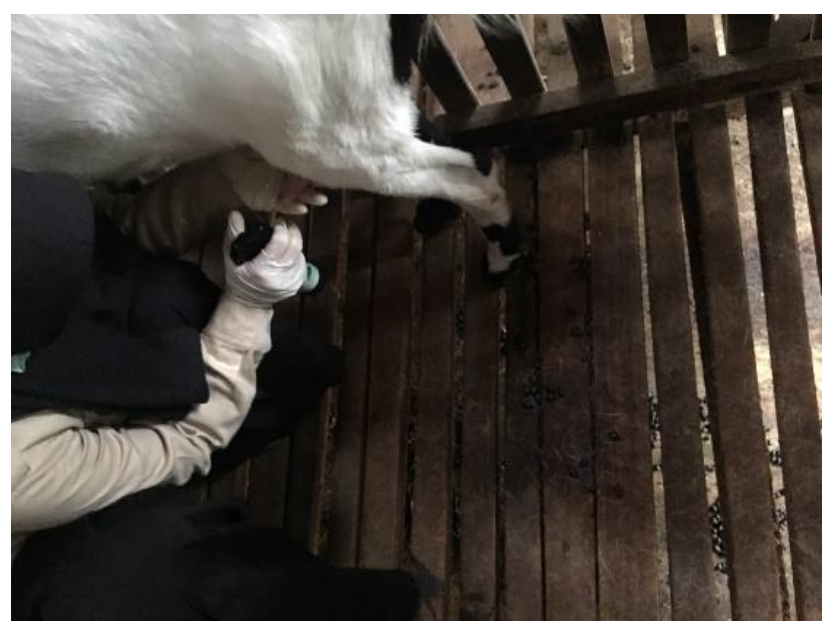

Gambar 2. Pendampingan kegiatan aplikasi teat dip sprayer

Proses penerapan teat dip sprayer dilakukan selama 28 hari masa pendampingan, tim pengabdian turut serta mendampingi serta memantau produksi susu harian ternak perah dengan bantuan kartu rekording (Gambar 3). 


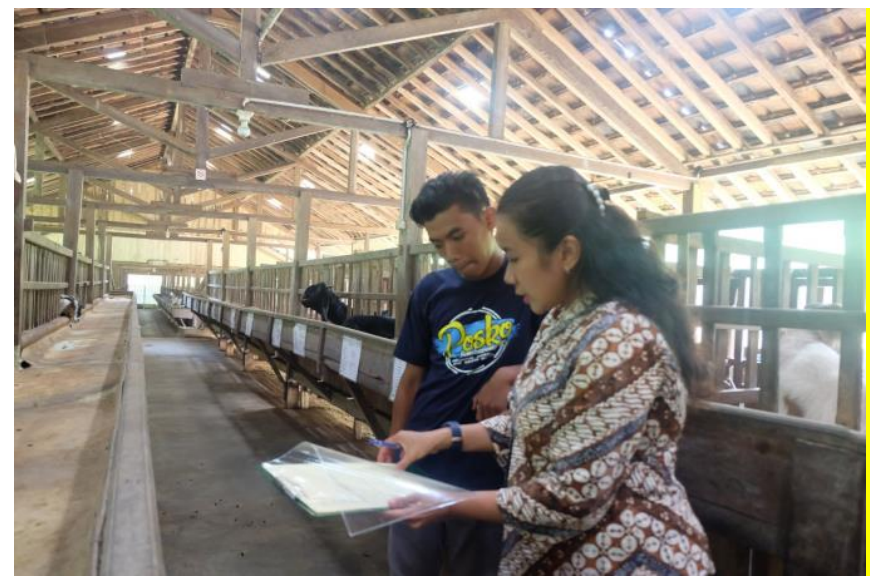

Gambar 3. Pemantauan kegiatan menggunakan data recording

\subsection{Evaluasi Kegiatan}

Evaluasi kegiatan pengabdian dilakukan dengan cara yaitu membandingkan pengetahuan dan pemahaman warga sebelum dan sesudah kegiatan menggunakan kuesioner dan keberlanjutan kegiatan dipping. Hasil yang diperoleh adalah meningkatnya pengetahuan peternak mengenai konsep GDFP dan pencegahan mastitis menggunakan daun sirih. Peternak mulai sadar akan pentingnya penerapan GDFP dan pencegahan penyakit mastitis. Pemberian teat dip sprayer secara rutin setelah pemerahan mampu menurunkan angka kejadian mastitis dibarengi dengan manajemen SOP pemeliharaan kambing perah yang baik. Pemberian teat dip sprayer ini tetap berlanjut meski kegiatan pengabdian telah selesai dilaksanakan.

\section{PENUTUP}

Berdasarkan hasil dari kegiatan pengabdian yang telah dilakukan dapat disimpulkan bahwa :

1. Kegiatan pengabdian ini dapat menambah wawasan peternak mengenai Good Dairy Farming
Practice (GDFP), penanganan mastitis menggunakan bahan herbal dan memanfaatkan pekarangan kosong disekitar kandang untuk ditanami tanaman sirih.

2. Kegiatan ini membantu peternak dalam upaya pencegahan mastitis subklinis dengan cara rutinitas kegiatan teat dipping sehingga diharapkan mampu meningkatkan produktivitas ternak perah.

Metode teat dip sprayer ini dapat diaplikasikan pada kelompok ternak lain baik pada kambing perah maupun sapi perah.

\section{DAFTAR PUSTAKA}

Anonim, 2017. Bidang Ketersediaan Pangan Badan ketahanan Pangan dana Penyuluhan Provinsi DIY. Workshop Neraca Bahan Makanan. https://bkpp.jogjaprov.go.id/content /read/865/Workshop-NeracaBahan-Makanan-(NBM)-

Artdita, CA., Lestari, BL., dan Tanzila, EP. 2017. Ekstrak daun sirih hijau 
(Piper Betle linn.) sebagai alternatif dipping ambing Peranakan Ettawa. Hibah peningkatan Kapasitas Peneliti Dosen Muda 2017.

Ceballos LS, Morales ER, Adarve GDLT, Castro JD, Martinez LP, Sampelayo MRS. 2009. Composition of goat and cow milk produced under similar conditions and analyzed by identical methodology. $J$ Food Comp Analysis. 22(4) : 322-329.

Dash, JR., Sar, TK, Samanta, I, and Mandal, TK. 2016. Effects of herbal extract of Ocimum sanctum as supportive therapy with intravenous ceftriaxone in experimentally induced staphylococcal chronic mastitis in goat. J. Small Ruminant Research 137:1-8.

Damayanti, R. dan Mulyono. 2005. Khasiat dan Manfaat Daun Sirih : Obat Mujarab dari Masa ke Masa. Jakarta: Agro Media Pustaka.

Flachowsky, G., Katrin, F., Meyer, U., Leiterer, M. 2013. Influencing factors on iodine content of cow milk. Europe. J. Nutr. 53: 351-365.

Indarwati $\mathrm{R}, \quad$ Herawati, dan Arisoesilaningsih, E. 2015. Strategic planning to develop good dairy farming practices in Smallholder Dairy Farms in Batu City, East Java. J-PAL. 6(2)163170.
Koop G, Werven T, Schuiling HJ, Nielsen M. 2010. The effect of subclinical mastitis on milk yield in dairy goat. J. Dairy Sci. 93(12):5809-5817.

Leitner G, Silanikove N, Merin U. 2008. Estimate of milk and curd yield loss of sheep and goats with intramammary infection and its relation to somatic cell count. Small Rumin Res. 74:221-225.

Leslie, K.E., Vernooy, E., Bashiri, A., and Dingwel, R.T. 2006. Efficacy of two hydrogen peroxide teat desinfectants, against Staphylococcus aureus and Streptococcus agalactiae. J.Dairy Sci. 89:3696-3701

Marogna G., Pilo C., Vidili A., Tola S., Schianchi G., Leori SG. 2012. Comparison of clinical findings, microbiological result, and farming parameters in goat herds affected by recurrent infectious mastitis. Small Rumin Res. 102:74-83

Tomita, T., Meehan, B., Wongkattiya, N., Malmo, J., Pullinger, G., Leigh, J. Deighton, M. 2008. Identification of Streptococcus uberis multilocus sequence types highly associated with mastitis. Appl. Env. Microbiol. 74:114-124

Yangilar, F. 2013. As a potentially functional food : goat's milk and products. Journal of food and nutrition research. 1(4):68-81. 